technologies move into the economic sphere and without an adequate referencing system it is hard to see how the book can be termed a guide in any sense of the word. It cannot be used to gain access to a wider world of knowledge about specific technologies, as in a hitch-hikers guide to new technology. Nor can it be used as a knowledge development tool in its own right, in the sense of a do-it-yourself action plan to new technology.

Somewhere in this volume is an interesting book trying to get out. The hyped-up, chopped-down delivery style appropriate to managerial seminars does not work in book format. Although the author may have a grasp of a wide range of recent scientific developments, his ideas about what these mean for the future are not effectively conveyed here. Perhaps the management seminars are better value. A treatment of these issues aimed at policy makers would be very appropriate during the current period of technological restructuring. It is a shame, but this is not the book.

Ken Ducatel is in the Department of Science and Technology Policy, University of Manchester, Oxford Road, Manchester M13 9PL, UK.

\section{Hidden message}

\section{John Galloway}

\section{Opportunities in Blology. National} Academy Press: 1990. Pp. 448. \$51.

There is a tale - I hope it is not apocryphal - that Sir Lawrence Bragg, asked by the $B B C$ to take part in a radio programme, refused - on the grounds that he did not think the country could afford to have a significant part of its scientific manpower out of action for an afternoon.

No such anxiety appears to have assailed the compilers of Opportunities in Biology. The book was put together by a committee of 20 of the most successful biologists in the United States, including luminaries such as Maxwell Cowan, Leroy Hood and Eric Kandel. By way of explanation, the preface says "no single individual can hope to grasp all the new activities and opportunities (of biology)". Nor could even 20 apparently, who were aided and abetted by a National Research Council staff of seven, eleven expert panels with at least six members each, a Board on Biology, a Commission on life sciences and 94 other contributors and reviewers.

What was it Horace said about the mountains labouring? Here we have not merely any old mountains but the Olympian peaks themselves, a couple of hundred of America's finest. Horace's mountains brought forth a mouse. What has the National Research Council been delivered of? The answer is not little, but is, I am sorry to say, of little value.

Apart from its subject, you judge a book by the quality of its language. That this is a book about biology, about ideas and methods that we can confidently expect to be unfamiliar to many of those at whom it is aimed - administrators and policy makers, for example - makes the proper use of language essential. And in its language, Opportunities in Biology leaves pretty much everything to be desired. It is remarkably sloppily written - it is not precise, economical, vivid, concrete and straightforward; it does not give sufficient apt detail to support the points it wishes to make; numbers are prominent only by their scarcity. The writers have included some graphic illustrations but appear to have chosen them at random without a decided or consistent purpose.

Let me give one or two examples of language used sloppily or wrongly - a few among many:

The word environment means surroundings. It does not need the adjective surrounding to precede it.

Epstein Barr virus (EBV) does not "carry" cancer. The virus is probably one of a chain of causes leading to Burkitt's lymphoma or nasopharyngeal cancer. (It is likely that EBV infects 90 per cent or more of the world's population but the cancers in which it is implicated occur in very few areas of the world.)

On page 43 , we are told that the largest single DNA that has been sequenced is the genome of EBV with 172,000 base pairs; and yet on page 46 that the genomes of organisms range in size from 750,000 to 3 billion base pairs. Whether or not a virus is an organism depends on your view point. But to read those two statements three pages apart without a word of explanation or qualification is simply unsettling. Incidentally, the longest single piece of DNA sequenced is now that of cytomegalovirus with 230,000 base pairs. This sequence, completed last year at the Laboratory of Molecular Biology in Cambridge, is only 30 per cent longer than that of EBV. This is worth mentioning because it suggests things are progressing relatively slowly in terms of sequencing complete DNAs. The optimistic note struck in Opportunities in Biology in writing about sequencing the human genome might have been tempered by this fact.

That the book is slightly out of date in respect of the cytomegalovirus genome is probably not very important. But it is out of date in more significant ways. Arguing for more research funding on the grounds that the United States is slipping against other countries in the quality of its biological research, figures of the number of US papers in the top 10 per cent worldwide are used. But the best that can be done apparently is to use data comparing 1973 with 1980. Data one to two decades old in a book like this are not good enough.

Picking up on Sir Lawrence's view point, I could not help irreverently wondering if one reason for the worsening performance of the United States is the extent to which its scientists are involved in exercises like this one.

Actually, I was almost more concerned with the quantity of language in the book than its quality. A large proportion of it seemed superfluous. And indeed genomes seem to offer a good way of illustrating the fault. It is usual to offer language as an analogy for the information contained in DNA. In viruses all the DNA is involved in the genetic message which is precise and compressed. On the other hand, in the human genome, 97 per cent of the DNA seems to have no purpose. The genetic messages are contained in about 3 per cent of the DNA. I could not help feeling that human DNA provides a useful analogy for language as it is used here. The messages in Opportunities in Biology are contained in a small fraction of the total words (the rest just has to be ploughed through).

The book also seems curiously muddled, both in small and large ways. The executive summary tells us of some of what biology has achieved by way of understanding. It then tells us "it is ironic that a time so filled with great opportunity should also be a time when a major fraction of the diversity of life on Earth is in danger of extinction". It is not ironic. The two facts are tightly tied to each other. The main problem the Earth faces is overpopulation by people and over-use of resources by a proportion of them, the end product of the "successful" application of scientific knowledge in the form of agriculture and medicine, for instance. I could not find a section about overpopulation, nor does it have an entry in the index. Where it might have been is the word ostrich - that does seem ironic.

What is strange about the flaws in the book is that 20 years ago the same exercise was undertaken in a volume called Biology and the Future of Man edited by Philip Handler, president of the National Academy of Sciences. It was very much better written and better at explaining some of the fundamental science. And it did conclude that population was the major problem for the immediate future. The earlier book was published just before two momentous pieces of biology - the discovery of a way of making monoclonal antibodies and the development of the technology for sequencing DNA which between them changed the face of biology almost beyond recognition. I would have thought that fact alone would have caused the writers of the present book to remind its readers that predicting what will happen is a somewhat uncertain exercise in science as elsewhere. 
I think if the National Research Council is thinking of doing this again it ought to attempt something more limited. The book is arguably an exercise in the public understanding of science, which has three different sides to it - its ideas and methods, its scope, and its relationship to society, government, industry, medicine and agriculture. A book beginning with a range of problems that face mankind and addressed by considering the scope of modern biology and how research is turned into action - and what sort - by industry or government would be extremely useful, or at least could be. To mix it up with attempts at Mickey Mouse explana-

\section{Moral dilemma}

\section{Philip Kitcher}

Created From Animals. By James Rachels. Oxford University Press: 1990. Pp.245. £17.50, \$19.95.

FREDERICK Banting and Charles Best spent most of the summer of 1921 in a small basement room at the University of Toronto, experimenting on dogs. Out of their work came the discovery of insulin, relief for millions of diabetics whose lives have been enormously prolonged through daily injections. Some of those who lived gave birth to children who would never have been conceived but for this discovery. I was one such child, one of the many who owe their lives to Banting and Best.

The work that led to the discovery of insulin involved considerable human sacrifice and suffering. Banting and Best were ultimately rewarded, primarily with the satisfaction of having made a remarkable medical advance, secondarily with high honours in the scientific world. But other actors in the drama were not so fortunate. Dogs do not win Nobel prizes. They are "sacrificed" for the advance of human science.

Can such sacrifices be justified? Are human beings morally entitled to use nonhuman animals to advance human welfare? Reflecting on the discovery of insulin, many people - especially, perhaps, those whose lives were made possible by it - will regard the question as frivolous. It is sad, of course, that the dogs in the Toronto basement had to suffer, sad but necessary. When we look at the great good that has ensued, the sufferings, the deaths, are justified. Would we say the same if Banting and Best had operated on people, if they had coerced adults against their will, or used orphaned children, or performed their operations on severely deformed neonates? In those circumstances, would we also have been prepared to judge that the wonderful consequences justify the means? tions of protein crystallography and the rest of molecular biology is simply not very helpful. Furthermore, books constructed on the basis of panel discussions need the iron hand of a very determined editor to lick them into shape.

But why not commission someone to write the book for them? A decent science writer could do this without the need for a huge formal structure of committees and panels - and I am sure Sir Lawrence would have approved.

John Galloway is at the Cancer Research Campaign, 2 Carlton House Terrace, London SW1Y 5AR, UK.

Again, these questions and the comparison they embody are likely to appear impertinent. Surely people are different from other animals, there is something special about human worth, human value, the dignity of human life. In light of that difference, that special something, we are entitled to do things to other animals that we should not do to people. Banting, Best and countless other scientists are morally justified in using nonhuman animals for medical research. The Nazi doctors who used human subjects in their "experiments" were moral monsters.

James Rachels' lucid, thoughtful and wellargued book leads us towards an uncomfortable re-evaluation of the simple distinction between people and other animals. Created From Animals ends where I have begun, with reflections on the use of animals in scientific research. The discovery of insulin is my case, not his, chosen to highlight some disturbing implications of the moral view that he develops. For Rachels' argument, grounded in an appeal to darwinian evolutionary theory, is that a simple reliance on the special worth of human beings cannot be sustained. If we are to draw a line between Banting and the Nazi doctors, then we must develop a more sophisticated moral view.

Rachels begins with an accessible account of Darwin's discoveries and a penetrating critique of some misguided proposals for relating ethics to evolutionary theory (primarily those of Herbert
Spencer and contemporary human sociobiologists). He then argues that Darwin undermined any substantial commitments in theology: consistent darwinians, Rachels claims, must abandon the central tenets of Christianity. Here, it seems to me, different audiences will be more or less challenged. Southern Baptists are likely to agree that the doctrines Rachels banishes are constitutive of "real religion"; liberal Anglicans are far less likely to be perturbed.

In any event, Rachels' main point is that darwinism undermines the doctrine that human beings have special worth and dignity by virtue of some human relationship to a deity.

The moral separation of humans and nonhumans must thus, he believes, depend on the differences between our species and others. But what kinds of difference might be morally relevant? Sensibly enough, Rachels focuses on sensitivity to pain and the capacity for intelligent behaviour. Appealing to studies of animal behaviour, he then builds a powerful case for claiming that the

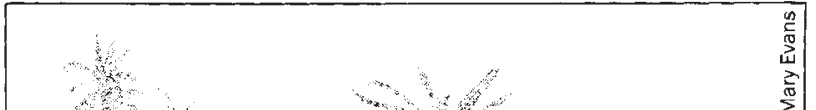

Sou! mates? - Do humans "have special worth and dignity by virtue of some relationship to a deity"? 